Corresponding Author: Rahmi Pramulia Fitri S Rahmipramulia86@gmail.com

Received: 18 January 2019 Accepted: 26 February 2019 Published: 12 March 2019

Publishing services provided by Knowledge E

(c) Rahmi Pramulia Fitri S. This article is distributed under the terms of the Creative Commons Attribution License, which permits unrestricted use and redistribution provided that the original author and source are credited.

Selection and Peer-review under the responsibility of the 1st PANIHC Conference Committee.

\section{The Correlation Between Environment Sanitation and the Infancy Diarrhea in the Working Area of Rejosari Central Health}

\author{
Rahmi Pramulia Fitri S
}

Public Health Program STIKes Payung Negeri Pekanbaru

\section{Abstract}

Diarrhea is an endemic in Indonesia and become one potential KLB disease that is possible followed by death. In 2015, it is happened 18 times of KLB Diarrhea which is spreading in the 11 province, 18 regencies, with the patient of 1.213 people and death of 30 people (CFR 2,47\%). In the world, diarrhea becomes the second cause of infant death in the world. Some related factors to the diarrhea is caused by the water sanitation is not well, polluted by feces, less sanitation facilities (feces disposal is not clean), bad personal and environment sanitation. Infancy diarrhea incident can be said as social pediatric because diarrhea is one of the disease that exist in developed country. This research was quantitative research with analytical design of Cross Sectional approach with total population of 2.057 people and sample of 95 Respondents. Respondent univariate result which was got the diarrhea in the last 3 months was $58(62,1 \%)$ with risky waste treatment of 66 (69,5\%), risky clean water supply of 57 (60\%). The bivariate result, there was a correlation between waste management ( $p$ value 0,0001 ) and clean water supply (p0,0001) to the infancy diarrhea. It can be concluded that there is a correlation between waste treatments to the diarrhea incident by risky waste treatment will caused diarrhea 7 times greater. There is also a correlation between clean water supply and diarrhea incident by risky water supply will caused diarrhea 8 times greater.

Keywords: environment sanitation, infancy diarrhea, Pekanbaru, 2018

\section{Introduction}

Diarrhea becomes one of the main health problem in developing country, including Indonesia. In Indonesia, diarrhea is one of the main death causal after respiratory infection (Maryunani, 2010). Diarrhea is an endemic disease in Indonesia and one of the KLB potential which is always followed by death. In 2015, there are 18 times KLB Diarrhea which is spread in 11 provinces, 18 regencies, with the patient of 1.213 people and death of 30 people (CFR 2,47\%). Case Fatality Rate (CFR) in KLB diarrhea is expected <1\%. It can be seen in KLB diarrhea recapitulation from 2008 to 2015 , that the CFR when KLB is 
high (>1\%) except CFR of 2011 when KLB 0,40\%, while in 2015 diarrhea CFR is increased into $2,47 \%$ [1].

In the world, diarrhea becomes the second causal of infant death rate. Almost 1 of 5 infant death which means 1,5 million each year because of diarrhea. Diarrhea causes more death on infant than AIDS, malaria and measles. The highest infancy diarrhea is existing in South Asia in the amount of 783 million, then Africa in the amount of 696 million, part of the world of 480 million and East Asia and Pacific in the amount of 435 million [2].

Diarrhea is one of the stomachache that often experienced by children, especially toddler and infant [3]. Diarrhea is not normal defecate or liquid feces with the frequency of 3 times or more to be happened in 24 hours [4]. Diarrhea is a condition where somebody defecates with the liquid feces, or maybe only water with more often frequency (usually 3 times or more) in a day [1].

According to Survey of Household health (SKRT), Mortality Study and Research of Basic Health annually, it can be known that diarrhea is still the main death causal of infant in Indonesia. The death main causal by diarrhea is caused by the less good governance, either in the home or health facility. Five regencies have been curing and treating the existing diarrhea patients in the area which surpass the target. However, there are also Regencies which the cured and treated diarrhea percentage is low, it is in Pekanbaru (36,06\%) and Kuantan Singingi Regency (41,91\%). The low percentage of cured and treated diarrhea in Pekanbaru is caused by less reporting from the health facility.

Based on the Survey of Diarrhea Morbidity result which is done by the Diarrhea Subdit of Health Ministry of RI in 2010, most of diarrhea patient did not come to the health facility. Some patient treats the diarrhea by themselves, some of them also come to private doctor, some comes to Health Center, Hospital and there is also never visited the health facility. Moreover, based on the Research of Basic Health in 2007 states that the diarrhea prevalence is higher in a village rather than in a city [5].

Sanitation becomes one of the healthy environment components, it is the intentional behavior to culture the healthy life to prevent human directly in contact with dangerous waste, in hope for keeping and increasing human health. In the implementation in society, sanitation covers the water supply, waste treatment, garbage treatment. Environment sanitation is an environment health status which covers the house hygiene, waste treatment, clean water supply and etc [6]. Infancy diarrhea incident can be said as social pediatric because diarrhea is one of the main disease which is existed in developing country, where there is a factor that influenced infancy diarrhea, the causal factors are agent, host, and environment. Some factors related to diarrhea is because the clean 
water supply is inadequate, water polluted by feces, less health facility (feces waste that is not hygienic), bad personal and environment hygiene, underdone food supply and cooked food is stored in not proper storage, so they become the factors of infancy diarrhea [7]:

Water waste treatment or water disposal is the rest of water that is disposed comes from household, industry or another public places, and generally contain dangerous substance for human health also disturbed the environment [6].

According to Tambuwun research [8], about Environment Sanitation to the Child in the Age of School Bahu Manado Health Center Working Area, the research shows the diarrhea of school children in Bahu Manado health center working area, most of the children is not experienced diarrhea. Environment Sanitation to the school children in Bahu Manado Health Center working area is considered good. There is a correlation of environment sanitation with diarrhea incident of school-age children in the working area of Bahu Manado Health Center $(p<0,05)$.

Based on Rachim research [9], about The Environment Sanitation Condition to the Infancy Diarrhea Incident in the Working Area of Baranti Health Center in Sidrab Regency in 2013 , by the research result, it can be concluded some conclusion: in clean water supply variable cannot be statistically tested. $(p$ value $=-$ ) >alpha (á $=0,05$ ) diarrhea incident. ( $p$ value $=0,000$ ) <alpha (á $=0,05$ ). In garbage variable, there is no correlation between garbage and diarrhea incident. $(p$ value $=0,947)>$ alpha $(a ́=0,05)$ in water waste disposal drainage, there is a correlation between water waste disposal drainage to the diarrhea incident. ( $p$ value $=0,000)<$ alpha $(a ́=0,05$ )

Based on the data that the researcher gets from the City Public Health Office (DKK) of Pekanbaru in 2016, the total of diarrhea patient is 8.968 people. The highest rate in Rejosari Health Center is 921 cases of diarrhea patient followed by Pekanbaru City in the number of 817 cases. While for the lowest finding rate in Langsat Health Center is in the number of 86 Cases of Diarrhea Patients. According to the above description, the researcher is interested to study about "The Correlation Between Environment Sanitation and the Infancy Diarrhea in Rejosari Health Center in Pekanbaru in 2018".

\section{Method and Instrument}

\subsection{Method}

This research was quantitative with analytical design through Cross Sectional approach. In the study of Cross Sectional, where the subject was observed once only through the 
measurement and observation to the variable at the same time, in purpose of looking at the independent variable and dependent variable which was done during the data analysis.

This research was conducted in the Working Area of Rejosari Health Center in Pekanbaru. The time of the research was done in January 2018- August 2018.

This research population was a mother who had an infant in the Working Area of Rejosari Health Center in Pekanbaru in the number of 2.057 people. Sample was the part of population which represented the population. In this research, the sample was 95 people. The sample collection was based on Slovin calculation. The sampling technique which was going to use in this research was Stratified Random Sampling

\subsection{Instrument}

In this research, the instrument which was going to use was Observation Sheet, which contained questions related to the problem. Questionnaire was arranged by the researcher and as simple as it was to be easily understand by mothers who had infant in the Working Area of Rejosari Health Center. Questionnaire which would be distributed had been tested in validity and reliability.

The collected data in this research was primary and secondary data. The secondary data collected from the existing data in the Sukaramai Village profile in Pekanbaru. The primary data was collected by questionnaire, interview to the research subject and direct observation in the research location.

\section{Result}

\subsection{Univariate analysis}

The Research is conducted in the Working Area of Rejosari Health Center in Pekanbaru. The univariate analysis result describe about the independent and dependent variable. Dependent variable which is elaborated as follows below is the incident of infancy diarrhea and the independent variable is the waste treatment, clean water supply, food supply and storage. 


\subsubsection{Diarrhea incident}

According to table.1, there are respondents who had experienced diarrhea in the last 3 3 months is in the amount of $58(62,1 \%)$ with risky waste treatment of $66(69,5 \%)$, risky clean water supply of 57 (60\%).

\subsubsection{Bivariate analysis}

The bivariate analysis result knows the correlation of research independent and dependent variable as follows:

TABLE 1

\begin{tabular}{|c|c|c|c|c|c|c|c|}
\hline \multirow[t]{3}{*}{ Variable } & \multicolumn{5}{|c|}{ Diarrhea Incident } & \multirow[t]{3}{*}{ P Value } & \multirow[t]{3}{*}{ OR (95\% Cl) } \\
\hline & \multicolumn{2}{|c|}{ Diarrhea } & \multicolumn{2}{|c|}{ No Diarrhea } & \multirow{2}{*}{$\begin{array}{l}\text { Total } \\
\text { n (\%) }\end{array}$} & & \\
\hline & $\mathbf{n}$ & $\%$ & $\mathbf{N}$ & $\%$ & & & \\
\hline \multicolumn{8}{|c|}{ Waste Treatment } \\
\hline Risky & 50 & 75,8 & 16 & 24,2 & $66(100)$ & 0,000 & $\begin{array}{c}6,944 \\
(2,963-18,271)\end{array}$ \\
\hline Not Risky & 9 & 31 & 20 & 69 & $29(100)$ & & \\
\hline Total & 59 & 62,1 & 36 & 37,9 & $95(100)$ & & \\
\hline \multicolumn{8}{|c|}{ Clean Water Supply } \\
\hline Risky & 46 & 80,7 & 11 & 19,3 & $57(100)$ & 0,000 & $\begin{array}{c}8,042 \\
(3,144-20,569)\end{array}$ \\
\hline Not Risky & 13 & 34,2 & 25 & 65,8 & $38(100)$ & & \\
\hline Total & 59 & 62,1 & 36 & 37,9 & $95(100)$ & & \\
\hline Not Risky & 9 & 24,3 & 28 & 75,7 & $37(100)$ & & \\
\hline Total & 59 & 62,1 & 36 & 37,9 & $95(100)$ & & \\
\hline
\end{tabular}

\subsection{Bivariate analysis}

According to bivariate analysis result in table 1.2, it can be concluded that:

1. There is a correlation between waste treatments to the diarrhea incident. Respondents with the risky waste treatments had a chance to experience diarrhea 6,9 times more in comparison with the respondents who treats the waste which is considered not risky

2. There is a correlation between clean water supply and the diarrhea incident. Respondents with risky clean water supply will experience diarrhea 8 times more than the respondents with not risky clean water supply 


\section{Discussion}

\subsection{Bivariate analysis}

\subsubsection{The correlation of waste treatment and diarrhea incident}

There is a correlation between waste treatment and diarrhea incident. Respondent with the risky waste treatment will experience diarrhea 6,9 times more than the respondents with not risky waste treatment.

The bad garbage treatment can trigger the high solidity of vector (flies, mice, cockroaches, mosquitos, and etc.) that can cause some health problem, one of it is infancy diarrhea, it is because the immunity of infant still weak.

\subsubsection{The correlation of clean water supply and the diarrhea incident}

There is a correlation to the clean water supply and the diarrhea incident. Respondent risky clean water supply will experience diarrhea 8 times more than the respondent with not risky clean water supply. Main water resource for drink is one of the sanitation facilities which are considered important related to the diarrhea incident. Some infectious germ which cause diarrhea is transmitted through oral fecal. The germs can be transmitted by entering the mouth, liquid that is polluted by feces, for example drinking water, fingers, and food which is prepared in the pot with polluted water.

The collected data shows the respondents with not proper clean water facility and not having diarrhea is 11 respondents $(19,3 \%)$, this is because, even though, the water is being consumed is not properly as the clean water supply but for the drinking needs, the respondents has cooked the water earlier, so when it is boiled and most of the respondents always gather the water for drinking an cooking in closed pot, so there is a little chance to be contaminated by bacteria that causes the diarrhea. Beside that, there are 13 respondents $(34,2 \%)$ that has the proper clean water supply facility but causes diarrhea. This is because some of the respondents still gather the water for drinking and cooking needs in an open pot and there are many toilets and the clean water resource is less than 10 meters range, so there is a big chance of contaminated by bacteria that causes the diarrhea. 


\section{Conclusion}

There is a correlation between waste treatment and the diarrhea incident. The respondent with risky waste treatment will experience diarrhea 6,9 times more than the respondents with not risky waste treatment. There is a correlation between clean water supply and diarrhea incident. The respondents with risky clean water supply will experience diarrhea 8 times more than the respondents with not risky clean water supply.

It is better to have a cooperation with the government, private and society to increase hygiene and healthy life. Communication, information and education about diarrhea need to be held continuously to increase the society knowledge in the attempt to increase hygiene and healthy life.

\section{Funding}

This research was funded by STIKes Payung Negeri Pekanbaru in 2017-2018.

\section{Acknowledgement}

In writing this research report, I cannot finish it without the helps and directions of various parties sincerely. For this reason, on this occasion researcher wants to express her deepest gratitude to the entire family of STIKES Payung Negeri Pekanbaru which provided moral and material supports. The team mates of this research who helped her carry out this research's activity. Her beloved mother and father who endlessly gave prayers, love, motivation and moral and material support to the researcher to complete this research and to all families who always pray and encourage her.

\section{Conflict of Interest}

The authors have no conflict of interest to declare.

\section{References}

[1] Health Department of RI. (2011). Pocket Book of Health Worker.

[2] Ariani. (2016). Diarrhea, Prevention \& Its Cure.

[3] Ardinasari. (2016). Smart to Prevent \& Cure Toddler \& Infant Disease Book.

[4] Maryanti, D. (2011). Neonatus Learning Book, Toddler \& Infant. 
[5] Dharma K. (2011). Nursery Research Methodology. East Jakarta: CV. Trans Info Media.

[6] Mundiatun. (2015). Environment Health Management. Yogyakarta: GAVA MEDIA.

[7] Umiati. (2010). The Correlation Between Environment Sanitation to the Infancy Diarrhea Incident in Nogosari Health Center Working Area Boyolali Regency.

[8] Tambuwun, F. (2015). The correlation of environment sanitation to the school-age children in bahu manado health center working area.

[9] Rachim. (2014). The correlation of environment sanitation condition to the infancy diarrhea incident in baranti health center working area sidrap regency in 2013, VII(1). 